\title{
Taiteesta kirjoittamisesta
}

\section{Asta Kihlman}

doi.org/10.23995/tht.112292

Artikkelissa hahmotetaan niitä eroja ja samuuksia, joita kaksoisrooli tieteentekijänä ja päivälehden kuvataidekriitikkona pitää sisällään.

Asiasanat: kirjoittaminen, kuvanluenta, nykytaide, taidehistoria, kuvataidekritiikki, Roland Barthes, Olli Keränen 
2000 merkkiä, kaksi palstaa, yhdessä kuvassa koko näyttely. Yleiskieltä ja tiivistystä. Piilottaisinko tekstiin alkusointuisen alliteraation, kuvan kevään kutsun?

Päivälehden kuvataidekritiikki on puettu usein tiukkoihin yleiskielen raameihin, mutta toisinaan niissä välkähtää pilkahdus queeria, hedelmätöntä hekumaa, verbaalista ilottelua, joka asettuu teoksen rinnalle itsenäisenä ja omalakisena, kielenä. ${ }^{1}$

Valo on tilaa, vehreys monisävyistä syvää vihreää. Talven sävypelkistys ei istu koloristin palettiin. $^{2}$

Ranskankielinen sana essai tarkoittaa kokeilua tai yritystä. Tässä esseessäni koetan hahmottaa niitä eroja ja samuuksia, joita kaksoisroolini tieteentekijänä ja päivälehden kuvataidekriitikkona pitää sisällään. Ilmiselviä samuuksiahan löytyy paljon. Molemmissa on kyse kielestä, molemmissa on kyse kuvista.

Pohdintani keskittyy kieleen tai kirjoittamiseen ymmärryksen välineenä. Kuvan ja kielen, kuvaluennan rajoja pohti myös Roland Barthes todetessaan, että "kriitikko ei voi riisua kohdettaan paljaaksi, ja niinpä ainoa mitä hän voi työssään paljastaa on kieli itse". ${ }^{3}$

\section{Tutkimuksen ja kritiikin kirjoittamisen samuuksista ja eroavaisuuksista}

Taiteentutkija lähestyy visuaalisia objektikategorioita - maalauksia, veistoksia, valokuvia, performanssia, grafiikkaa, installaatioita, me-

1 Ks. myös Harri Kalha, "Kirjoittaminen On," teoksessa Kritiikin ääniä. Tekstejä kritiikistä 2020, toim. Mari Hyrkkänen, Riikka Laczak \& Maria Säkö (Helsinki: Suomen arvostelijain liitto, 2020), 14-24.

2 Asta Kihlman, "Sigrid Schauman ja valon kuvat," Turun Sanomat 28.4.2021.

3 Roland Barthes, The Rustle of Language (Berkeley \& Los Angeles: University of California Press, 1966 [1989]), 37. diataidetta, yhteisötaidetta tai biotaidetta - ymmärtäen, että jokainen aikakausi ja jokainen uusi taidekäsitys määrittyy oman kontekstinsa ehdoilla. Analyysinsä apuna taiteentutkija voi käyttää teoriaa, kiinnittää huomiota teoksen materiaaliestetiikkaan ja formalistisiin ominaisuuksiin tai hyödyntää käsitteitä kuten mimesis, konteksti tai muisti. Historiallista aineistoa tulkittaessa symbolit ja allegoriset konventiot antavat vihjeitä tulkinnalle: Maerten Boelema de Stommen Asetelman (1642) eksoottinen sitruuna ja nautiluksen kuoresta valmistettu malja toimivat kuvan lukijalle embleemeinä Hollannin kaupankäynnin avulla avautuneesta maailmasta.

Taiteen muoto- ja ilmaisukielen analyysi ja sisällön tulkinta ovat olennainen osa taiteentutkimusta. Taide ei pelkästään heijasta vaan myös tuottaa merkityksiä. ${ }^{4}$ Taiteilijan tuotannosta voi lukea yhtä hyvin "ilmeisiä" kuin myös vähäpätöisiltä tuntuvia merkityksiä. Taide paljastaa katkelmia tekijän ajattelusta, kokemuksesta tai mielikuvituksesta. Kuvat heijastelevat myös niitä diskursseja, joiden vaikutuspiirissä taiteilija eli ja työskenteli. ${ }^{5}$

Teoksen erityisluonne ei siten ole niinkään löydettävissä irrallisista muotoelementeistä kuin siitä, miten taide muoto- ja ilmaisukielensä avulla ja rajoissa tulkitsee inhimillistä kokemustodellisuutta - miten teos puhuu maailmasta ja vaikuttaa maailmassa. ${ }^{6} \mathrm{Se}$, mikä kuvassa on olennaista, on kuitenkin muuttuvaa. Teos säilyy ulkoisesti muuttumattomana eri aikakausien esittäessä sille kysymyksiään. Kysymysten muuttuessa myös vastaukset muuttuvat. $^{7}$

4 Leena-Maija Rossi, Taide vallassa. Politiikka-käsityksen muutoksia 1980-Iuvun suomalaisessa taidekeskustelussa (Helsinki: Taide, 1999), 21.

5 Asta Kihlman, "Kolme tutkielmaa sukupuolesta," Lektio, Sukupuolentutkimus / Genusforskning nro 1 (2019): 34.

6 Yrjö Heinonen et al., "Taide, kokemus, maailma," teoksessa Taide, kokemus ja maailma. Risteyksiä tieteidenväliseen taiteiden tutkimukseen, toim. Yrjö Heinonen (Turku: Utukirjat, 2014), 14.

7 Kihlman, "Kolme tutkielmaa sukupuolesta," 34. 
Kuvataidekriitikko tarkastelee kielen avulla mitä taiteilija on tehnyt ja miten teoksen visuaalispoliittinen kiteytys onnistui. Ehkä ilmeisin ero tutkijan ja kriitikon välillä on se, että kritiikki on ollut luonteeltaan arvottavaa. Tosin tämä piirre on nykykritiikissä vaihtumassa kohti teoksen kontekstualisointia ja avaamista suurelle yleisölle. Kritiikki mielletään nykypäivänä ennen kaikkea kulttuurisen itseymmärryksen tilana ja välittäjänä, sillanrakentajana, keskustelun herättäjänä ja sen syventäjänä. ${ }^{8}$

Myös kritiikki tekstilajina on viime vuosina laventunut ja monipuolistunut. Kirjoittajan edustamasta traditiosta riippuen kritiikki voi kohdistua perinteisten taiteenlajien (kuvataide, musiikki, tanssi, teatteri, elokuva, arkkitehtuuri) lisäksi uudempiin taiteenlajeihin kuten sarjakuvaan ja sirkustaiteeseen sekä soveltavan estetiikan alueille kuten kaupunkiestetiikkaan, arjen estetiikkaan tai mille tahansa kulttuurin ja elämän osa-alueeseen, jota kirjoittaja tarkastelee erilaisten taiteen ja tieteen filosofioiden valossa. ${ }^{9}$

\section{Paljastaa taide ja kätkeä taiteilija}

Kuvataideteos on visuaalinen esitys, jota voi pitää eräänlaisena peilinä sen heijastaessa ja tuottaessa käsityksiä ympäröivästä maailmasta. ${ }^{10}$ Itsestään selvää tai yksiselitteistä taide - taiteentutkijan tai kriitikon tarkastelukohde - ei kuitenkaan milloinkaan ole.

Paul Osipowin 1970-luvulla valmistuneen $\mathrm{Ma}$ tala tila-maalauksen lähtökohtana on pesuhuoneen kaakeliseinä, mutta teos ei kuvaa valoja ja varjoja, halkeamia seinässä. Sen sijaan Osipow on toteuttanut sen kahta väriä - vaaleanpunais-

8 Sini Mononen \& Asta Kihlman, "Kritiikin eettiset ohjeet," kritiikinuutiset.fi/2021/01/31 https://www. kritiikinuutiset.fi/2021/01/31/kritiikin-eettiset-ohjeet-ovat-yhteisollista-ammattietiikkaa/.

9 Mononen \& Kihlman, "Kritiikin eettiset ohjeet".

10 Asta Kihlman, Kolme tutkielmaa sukupuolesta. Identiteettipolitiikka Beda Stjernschantzin, Sigrid af Forsellesin ja Ellen Thesleffin taiteessa (Turku: Annales Universitatis Turkuensis, 2018), 15. ta ja ruskeaa - käyttäen. Syntyy teos, joka on taiteilijan omin sanoin lähellä "olemattomuutta". ${ }^{11}$ Osipowin värikenttämaalauksissa ollaan usein lähellä olemattomuutta, kun aihe on yksinomaan ele, ei teoksen päätepiste. Teosten teoreettinen selittäminen on taiteilijan mukaan epävarmuutta. ${ }^{12}$ Se peittää taiteen idean, kokemuksellisen liikkumavaran.

Suomalaisen taiteen klassikoita uudelleen tulkinnut ja muun muassa Vänrikki Stoolin tarinat uudelleen kuvittanut ruotsalaistaiteilija Ernst Billgren on kiteyttänyt kysymyksen "mitä taide on?" seuraavasti: "samassa mielessä kuin fyysikko on atomien joukko, joka yrittää selvittää mikä on atomi, taide on keksintö, joka yrittää selvittää mikä taide on".13

Teemu Mäki on puhunut siitä, miten taidetta kohdatessamme yritämme aktiivisesti hakea teoksesta heijastuspintaa ajatuksillemme ja siten sommitella niistä itsellemme kokemuksia. Meillä on tietoinen tai tiedostamaton käsitys taiteen tehtävästä, niistä asioista, joita taiteelta on meidän mielestämme mielekästä odottaa ja toivoa. ${ }^{14}$ Taide on kuitenkin monessa mielessä illuusio. Kuten 1600-luvun trompe l'oeil -aiheet, taide saa nykypäivänäkin katsojan uskomaan kuvaan, uskomaan sen käsinkosketeltavuuteen, todellisuuteen. Illuusion särkyminen kylvää epäluulon siemenen kaikkea kuvallista esittämistä kohtaan:

11 Paul Osipow, "Kertomus matalasta tilasta," Taide nro 2 (1974): 38.

12 Sini Mononen, "Paul Osipow ei halua tunkea taidetta teorian "liian pieniin kenkiin" - Taidehallin näyttely esittelee arjen havaintoja ja vahvoja perusvärejä kuudelta vuosikymmeneltä," Helsingin Sanomat 1.2.2019.

13 Ernst Billgren, Mitä on taide ja sata muuta tositärkeetä kysymystä (Helsinki: Teos, 2010), 4.

14 Teemu Mäki, Taiteen tehtävä, esseitä (Helsinki: Into, 2018), 46. 
entä jos kuvan takana ei koskaan olekaan kuin toinen kuva (kuvan konteksti) ${ }^{15}$

Jokainen kuva vaatii meiltä aktiivista osallistumista. Kuva voi olla sekä eleen pysäytys, asetelma tai asento että ele, joka vaatii ajattelemaan, jatkamaan sen implikoimaa liikettä. ${ }^{16}$ Yhteiskunnassa vaikuttavat, nopeasti liikehtivät omalakiset ja monimutkaiset arvorakennelmat saavat kiteytyksensä usein juuri ensimmäisenä taiteessa. Nykytaiteessa erilaiset aistinvaraiset - maun ohella myös molekyylikontakteihin eli tuoksuihin perustuvat teokset ovat arkipäivää. Sienten ja homeiden yhteiseloa tai mustekalojen ja tekoälyn kommunikaatiota tutkivat teokset esittävät hankalia kysymyksiä elintilasta ja epävarmasta tulevaisuudesta. (Nyky)taide ei julistakaan totuuttaan nopeasti tai yksiselitteisesti vaan pyytää katsojaa mukaan kuvien merkityksenantoon ja tulkintakehysten valintaan.

Siksi teosta voi ainoastaan lukea, pyrkiä kirjoittamaan sitä "auki" tunnustelemalla sitä ympäröivää kulttuuria ja saattamalla sen rinnalle erilaisia tekstejä, jotka avaavat kohteeseen uusia näkökulmia ja syventävät jo olemassa olevia. Taidetta ei voi eikä ole mielekästäkään täsmällisesti määritellä, sillä taiteella ei ole "perinteistä olemusta", johon sen voisi palauttaa ajasta, paikasta ja kontekstista riippumatta. Taide on aina sopimuksenvarainen asia. ${ }^{17}$ Mika Elo mukailee Heideggerin ajatusta seuraavasti:"Kankaalle maalatut kengät on tuomittu mykkään litteyteen, vasta kuvan lukija saa ne liikkeelle". ${ }^{18}$

15 Riikka Stewen pohtii artikkelissaan "Esineiden maailma" illusionismia Trompe l'oeil-käsitteen kautta. Riikka Stewen, "Esineiden maailma," teoksessa Esineiden maailma, toim. Riikka Stewen \& Susanna Santala (Helsinki: Suomen Taideyhdistys, 2005), 10.

16 Mika Elo, "Esinemaailman allegorisia figuureja: asetelma, asento, ele," teoksessa Esineiden maailma, toim. Riikka Stewen \& Susanna Santala (Helsinki: Suomen Taideyhdistys, 2005), 78.

17 Mäki, Taiteen tehtävä, esseitä, 42.

18 Ks. esim. Elo, "Esinemaailman allegorisia figuureja," 73. Elo pohtii artikkelissaan kuvan ja esineen välisiä vuorovaikutussuhteita.
Oscar Wilde muotoili Dorian Grayn muotokuva -romaaninsa esipuheessa, että taiteen tehtävä on paljastaa taide ja kätkeä taiteilija. ${ }^{19}$ Kun taiteentutkija ja kriitikko kysyvät teokselta mistä siinä on kyse, vastauksia saadaan ja niitä etsitään eri paikoista.

Taiteentutkija esittää aineistolle kysymyksen, teesin tai hypoteesin, ja mahdollisesti tuottaa uuden näkökulman aiheeseen. Historialliseen aineistoon keskittyvä tieteentekijä voi pitää esimerkiksi ranskalaisfilosofi Michael Foucault'n ajatuksia kirjailijan tuotannon rajoista ohjenuoranaan tutkimusta tehdessään. Foucault'n mukaan muistikirjamerkinnät ja luonnokset, päiväkirjat ja kirjeet ovat merkityksellistä materiaalia suhteessa "varsinaiseen tuotantoon". ${ }^{20}$ Historiallista kuvaa tutkivalle teos on merkki olemassaolosta, jonka evidenssinä toimivat taiteilijan koko henkilöhistoria, erilaiset ajatussysteemit ja teoriat. Taiteentutkija haluaa paljastaa sekä taiteen että sen taustalla olevan taiteilijan.

Toisaalta jo varhaisromantiikasta juontuu käsitys, jonka mukaan kaikki teokset ikään kuin imevät itseensä kaikki edeltävät teokset ja tuottavat siten seuraavan teoksen. Yksittäisen taideteoksen intertekstuaalinen avaruus on näin ajateltuna ääretön. Intertekstuaalisuus on siten mukana myös kaikessa lukemisessa, tulkitsemisessa ja kirjoittamisen prosessissa. Jokainen kuvanlukija voi teoksen äärellä esittää Roland Barthesia mukaillen kysymyksen: "mitä tämä teksti tekee minulle, mitä minä tässä tekstissä voin lukea minästä? ${ }^{21}$

Saksalainen nykytaiteentutkija ja kriitikko Jan Verwoert on esittänyt ajatuksen "suhteiden ener-

19 Oscar Wilde, The Picture of Dorian Gray (Buckingham: University of Buckingham Press, [1891] 2001).

20 Michael Foucault, "What is an author?," teoksessa The Foucault Reader, ed. Paul Rabinow (Harmondsworth: Penguin Books Ltd 1984), 103.

21 Ks. esim. Roland Barthes, Barthes by Roland Barthes (University of California Press: Berkeley \& Los Angeles [1977] 1994), passim. 


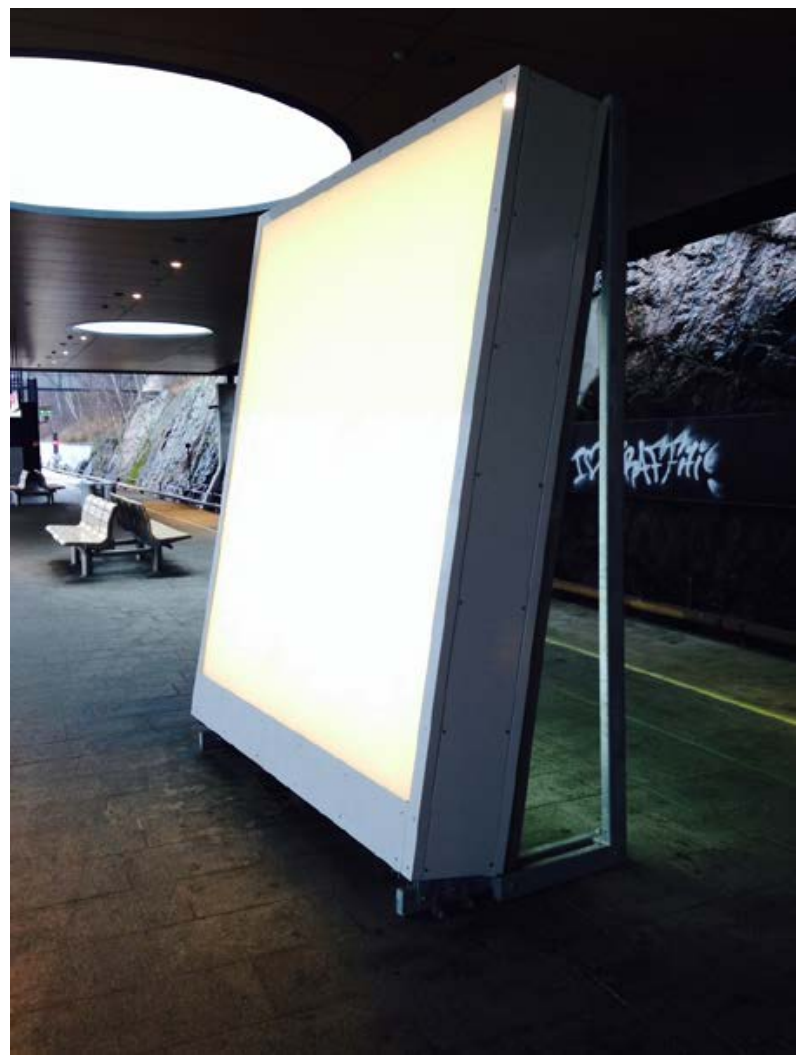

Kuva 1. Olli Keränen, Näin sinun tulevan, 2016, teoksen ensimmäinen osa. Kuva: Olli Keränen.

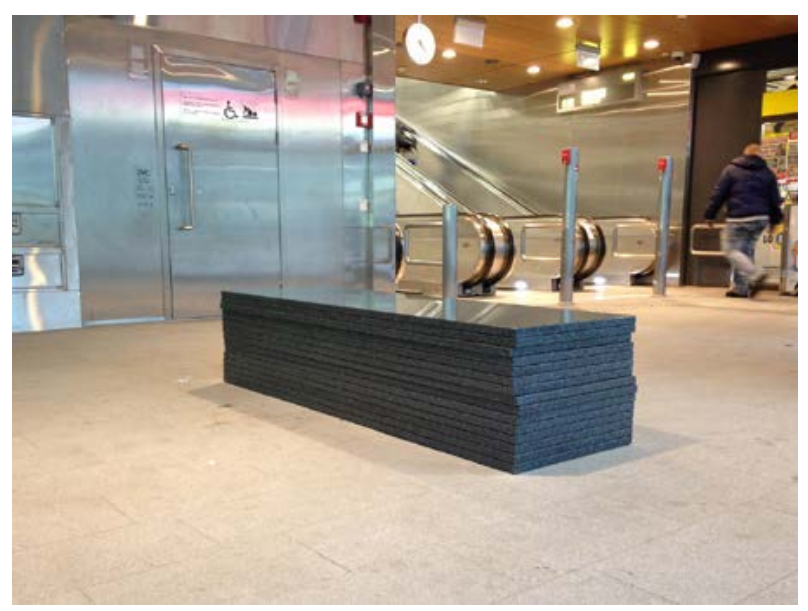

Kuva 2. Olli Keränen, Näin sinun tulevan, 2016, teoksen toinen osa. Kuva: Olli Keränen. giakentästä", joka sisältää myös objektin ja itsen vuorovaikutuksen. ${ }^{22}$ Verwoertin ajattelusta voidaan jatkaa myös siihen, mitä Walter Benjamin kutsui auraksi - esine, jonka osatekijöitä ovat aika ja tila, sekä ruumiiden ja kappaleiden monimerkityksellinen läheisyyden ja etäisyyden kudos. ${ }^{23}$ Kuva syntyy siten aina vuorovaikutuksessa kokijansa kanssa.

Nykytaiteessa monet historialliset hetket ovat aikalaisiamme, koska niiden herättämät kysymykset tuntuvat tärkeiltä.

Nykytaiteen fragmentaarisuus viittaa moneen suuntaan ja joskus sekä taide että taiteilija jäävät piiloon. Nykykuvan kielessä tyypillistä onkin, että teoksen ja dokumentin rajat kyseenalaistuvat. Sosiaalisesti jaettu tila mahdollistaa teoksen ilmenemisen esimerkiksi tekona, tapahtumana, ajatusmallina tai ideana. ${ }^{24}$

Taiteilija Olli Keräsen teos Näin sinun tulevan (2016) Siilitien metroasemalla pohtii teoksen ja katsojan välistä kommunikaatioyhteyttä. Kaksiosainen teos koostuu viidestätoista päällekkäin asetetusta kivilevystä muodostuvasta "veistoksesta", joka toimii myös istuimena, sekä suuresta odotuslaiturille asetetusta valotaulusta. Metron käyttäjästä tulee osa installaatiota, valotaulun valon muusta ympäristöstä poikkeavan värilämpötilan irrottaessa matkustajan muista matkaajista ja nostaessa tämän osaksi teosta. ${ }^{25}$

Ranskalainen kuvataidekriitikko Nicholas Bourriaud onkin puhunut nykytaiteen relationaalisesta estetiikasta. Ranskalaisfilosofi Althusserin

"HRS Lecture: Jan Verwoert," luettu 15.5.2021, https:// www.youtube.com/watch?v=gWjQaD9DGDo.

23 Elo, "Esinemaailman allegorisia figuureja: asetelma, asento, ele," 72.

24 Riikka Stewen \& Tuija Parvikko, "Taiteellisen toiminnan politiikkaa," teoksessa Nykytaidetta etsimässä, neljä keskustelua Kiasmassa, toim. Riikka Stewen, Riikka Haapalainen \& Kaija Kaitavuori (Helsinki: Like, 2007), 17.

25 Asta Kihlman, "Kommunikaation kolme tasoa," Turun Sanomat 16.11.2020. 
ajatteluun tukeutuen Bourriaud viittaa taiteeseen, jonka lähtökohtia ovat yksilöiden väliset vuorovaikutussuhteet ja sosiaaliset kontekstit. ${ }^{26}$ Tällöin taiteilija on pikemminkin prosesseja alullepaneva katalyytti kuin teoksen keskus.

\section{Kielellisiä yrityksiä kumota kaaos kosmokseksi}

Kriitikko pyrkii tekemään teoksesta tulkinnan etsimällä vihjeitä läheisyydestä ja etäisyydestä, mahdollisen ja mahdottoman samanaikaisesta kokemisesta. Kriitikon tehtäväksi muodostuu vihjeitä keräten kontekstualisoida teos suhteessa taiteenalansa kenttään, aikaansa sekä teosta kehystäviin ilmiöihin. Niiden avulla hän pyrkii löytämään, mikä teoksessa on kulttuurisesti arvokasta ja välittämään sen lukijoille. ${ }^{27}$

Taiteentutkijan ja kriitikon yhteinen tehtävä on purkaa teoksen muotoja ja struktuureja sekä pyrkiä osoittamaan teoksen taustalla vaikuttavia erilaisia ajatussysteemejä. Yhteistä molempien työssä on, että teos kokee käsittelyssä eräänlaisen dekonstruktion, purkamisen osiin. Nämä osat tutkija/kriitikko sitten kasaa uudelleen kielen avulla.

Harri Kalha on kuvaillut tätä taiteen kirjoittajan ikuista dilemmaa osuvasti:

Mutta kun pääsen kotiin, piskuisen portfolion anaalinen järjestys purkautuu äkkiä epämääräiseksi läjäksi pöydälle. Taidesalkku oli liian hyvä ollakseen totta. Toisaalta: Now we're talking. Tämä on sittenkin lähempänä totuutta. Eihän taidetta salkkuun voi sovittaa. Eikä tähän mitään siistiä symbioosia tarvitakaan. Vain minä (kynäni) ja sinä (teos), that’s it.

[...]ja kun yritän laittaa aineistoa takaisin, se ei enää mahdukaan pienen kansion sisään. Kaaos

Nicolas Bourriaud, Relational Aesthetics (Dijon: Les presses du reel, 2002), passim.

27 Mononen \& Kihlman, "Kritiikin eettiset ohjeet".

ei enää taivu kosmokseksi, tai sitten kansio on kutistunut. Käykö näin myös teoksille, kun ne puretaan verbaalisiin osiin? Käykö niin, ettei taideteos suostukaan enää ottamaan osasiaan vastaan, että Taide hylkii omiaan, kun ne ovat käyneet vieraissa? ${ }^{28}$

Kriitikko ei useinkaan valitse arvioimaansa teosta, tutkija valitsee aineistonsa. Aineisto puhuttelee tutkijaa, kriitikolle aineisto voi joskus olla mykkä. Se että aineisto pysyy mykkänä ja kosmos särkyy kaaokseksi, voi kritiikkiä tehdessä olla jopa etu. Ambivalenssi voi olla häiritsevää, mutta vieraudessaan myös kiehtovaa. Riikka Stewen on puhunut asetelmien yhteydessä siitä, miten niiden samanaikainen "vierauden ja tuttuuden tunne", sekä läheisyyden / etäisyyden dialektiikka johtavat auraattiseen vaikutelmaan. ${ }^{29}$ Emotionaalisesti äärirajoille menevä kokemus voi aiheuttaa subliimin kokemuksen.

Kriitikon jakamat tuntemukset ovat kuitenkin aina subjektiivisia. Monessa mielessä taiteesta kirjoittava on siten nykytaiteilijan tapaan prosesseja alullepaneva katalyytti. Kriitikko ehdottaa analyysiä, assosiaatioita, käsitteellisiä avauksia. Taiteentutkija pyrkii löytämään väitteensä tueksi evidenssiä, kirjallisia lähteitä ja väitteitä todistavia kuvia, mutta toimii eräällä tavalla yhtä subjektiivisesti kuin kriitikkokin assosiaatioitaan analysoiden. Esimerkiksi nykyteoriasta ammentava historiallisen kuvan tutkija tarjoaa teoksiin vain tulkintoja, tunnustelevia näkökulmia, osoittaen samalla kuvien mutta myös lukutapojen moninaisuutta.

Vaikka taiteesta kirjoittava pyrkii tiivistämään merkkijonoon näkemyksensä teoksen pyöreydestä, suoruudesta, kovuudesta, pehmeydestä, pinnasta ja syvyydestä ja pohtii siinä sivussa ehkä myös taiteen käsitettä ja hyvää makua, taiteentutkijan ja kriitikon teoksen/tekstin moniäänisyys

Harri Kalha, Timo Heino (Helsinki: Helsingin taidemuseo, 2013), 13.

Riikka Stewen, "Esineiden maailma," 11. 
resonoi aina kirjoittajan oman minän kanssa. Harri Kalhan mukaan taiteesta kirjoittaessa kirjoittaja kirjoittaa aina ja väistämättä taiteesta kirjoittamisesta ja kirjoittajasta itsestään. ${ }^{30}$

Taiteesta kirjoittamisen kieli on teoksen edessä aina tunnustelevaa. Samalla tavalla kuin visuaalisesti pelkistetyt teokset voivat poliittisesti olla kaikkein tehokkaimpia ja taiteellisesti yllättävimpiä myös teksti/teos tuottaa usein syvimmän mielihyvän juuri silloin, kun se onnistuu saamaan itsensä kuulluksi epäsuorasti - silloin, kun sitä lukiessa/katsoessa joutuu toistuvasti nostamaan päätään, kuuntelemaan jotain muuta. ${ }^{31}$

FT Asta Kihlman on turkulainen visuaaliseen kulttuuriin ja queer-tutkimukseen erikoistunut taiteentutkija. 